\title{
Is HYdE PARK Hiding THE TRUTH? AN ANALYSIS OF THE PUBLIC INTEREST DEFENCE TO COPYRIGHT INFRINGEMENT
}

\author{
Rachel A Yurkowski*
}

The existence, or not, of a public interest defence in the sphere of copyright law has been an issue of contention for many years. Due to the comprehensive statutory fair dealing defences available, only a handful of defendants have sought to rely on this defence, which exists at common law. However, when the defence has been raised, the judges have been unable to reach a consensus on its status, scope and indeed availability as a defence to breach of copyright.

This paper analyses the extent to which public interest concerns are addressed in statutory copyright law, and presents arguments in support of extending the common law public interest defence to copyright law. However, any such defence must be limited in its scope and applicability, so as to avoid becoming a "thieves charter".

\section{INTRODUCTION}

As a concept, copyright aims to reward a creator for the works derived from his or her mental efforts. It confers upon the creator the strongest interest known at law - a property right enforceable as against the world. However, it is not absolute; indeed, "every man holds his property subject to the general right of the community to regulate its use to whatever degree the public welfare may require it."1

\footnotetext{
Solicitor, Chapman Tripp Sheffield Young. This article was submitted in fulfillment of the LLB(Hons) requirements at the Victoria University of Wellington 2000.

1 Theordore Roosevelt, quoted in LR Patterson and SW Lindberg The Nature of Copyright: A Law of Users' Rights (University of Georgia Press, Georgia, 1991) 74.
} 
While the public interest in the dissemination of works is usually accommodated by the fair dealing exceptions present in copyright legislation, there will be circumstances where these defences are not available, either due to the nature of the copyright work or the use made of it. This does not necessarily mean that the copyright owner's rights will be unconditionally upheld. At common law, a public interest defence may be available in exceptional cases to justify the publication of a copyright work that would ordinarily be excluded from the specific fair dealing exceptions.

The suggestion of a separate public interest defence to actions for infringement of copyright is not new. In fact, the relevance of public policy and public interest considerations to the balancing act implicit in copyright law has been recognised in cases dating back to the early nineteenth century. However, the recent English cases of Hyde Park Residences Ltd $v$ Yelland and Ors ${ }^{2}$ (Hyde Park) and Ashdown v Telegraph Group Ltd ${ }^{3}$ (Ashdown) have reignited the discussion of the status of and justifications for a common law public interest defence within the realm of copyright.

This article seeks to clarify where the public interest defence stands in the realm of copyright. It suggests that, contrary to the English Court of Appeal's decision in Hyde Park and the judicial comments in Ashdown there are legal and policy reasons supporting the coexistence of a common law public interest defence with the statutory copyright regime.

It is be noted that, although this paper refers primarily to English law, the reasoning for and scope of the public interest defence to copyright infringement apply equally to copyright in the New Zealand context.

\section{FAIR DEALING - REPRESENTING THE PUBLIC INTEREST COMPONENT IN COPYRIGHT LAW?}

First recognised in England in 1802, the fair dealing defence was one of the earliest ways by which the rights enforceable under copyright could be overridden in certain situations. Although the Court did not use the expression "fair dealing," the judges held that, as long as any infringement was "fairly done ... for the benefit of the public", "a man may fairly adopt part of the work of another." ${ }^{4}$ The Copyright Act 1911 (UK) incorporated the first statutory fair

2 Hyde Park Residence Ltd v Yelland and Ors [1999] RPC 655 (HC Ch D) [Hyde Park (HC)]; Court of Appeal [2000] RPC 604 (CA) [Hyde Park (CA)].

3 Ashdown v Telegraph Group Ltd [2001] EWCA Civ 1142 [Ashdown].

$4 \quad$ Cary, above n 5, 171. 
dealing defence and it has been retained in all subsequent Acts. ${ }^{5}$ In its 1981 Green Paper, ${ }^{6}$ which preceded the Copyright Designs and Patents Act 1988 (CDPA), the British Government recognised that "the public interest demands that not every unauthorised reproduction of copyright material should constitute an infringement of copyright." ${ }^{17}$ The extent to which the fair dealing exceptions to copyright accommodates this public interest is unclear.

The uncertainty is due to the courts' inconsistent interpretation of the fair dealing provisions. Judges in cases in the 1970s took a narrow view of the statutory defence, ignoring public interest considerations in their analysis, and leaving open room for the recognition by some judges of a separate common law 'public interest' defence for situations not encompassed by the statutory exceptions. ${ }^{8}$

These cases were the basis for a campaign, led primarily by newspaper publishers, for the inclusion of a separate "public interest defence" in the CDPA. ${ }^{9}$ When the new copyright legislation was being debated in the House of Lords, the government rejected the addition of a separate public interest defence on the basis that the fair dealing defences sufficiently and exclusively gave deference to public interest considerations. ${ }^{10}$

More recent interpretations of the fair dealing defences by the English courts have reflected judicial favouritism for an expansive and liberal reading of the legislative provisions, culminating in the view held by some judges that the fair dealing defences sufficiently

5 Copyright Act 1956 (UK) and Copyright, Designs and Patents Act 1988 (UK).

6 Reform of the Law Relating to Copyright, Designs and Performers' Protection. A Consultative Document [Green Paper] (1981) Cmnd 8302 ["Green Paper"].

7 "Green Paper", above $n 7$ ch 3, para 1.

8 See Part III B below.

9 Report of the Committee to consider the Law on Copyright and Designs (1977) Cmnd 6732, para 667 ["Whitford Committee Report"].

10 Lord Beaverbrook stated that "[c]hapter III [which incorporates the fair dealing exceptions] sets out specific exceptions to copyright, all of them being judged to be in the public interest, and does so in a way in which, as far as possible, puts clear limits on the scope of the exception": (8 December 1987) 491 GBPD col 75-77. 
accommodate public interest concerns. For example, Lord Justice Walker in Pro Seiben Media AG $v$ Carlton UK Television Ltd (Pro Seiben) observed that: 11

[t] he wide variety of uses of copyright material permitted by the 49 sections comprised in Chapter III ... are all directed to achieving the proper balance between protection for the rights of a creative author and the wider public interest.

Similar sentiments were expressed by Justice Gummow in Australia, where the Copyright Act 1968 (Cth) follows the English 1956 legislation. His Honour commented in Collier Constructions Pty Ltd $v$ Foskett that: ${ }^{12}$

...it would be an odd result if this complex set of provisions, reflecting an accommodation by the legislature of a range of competing interests, were overlaid with some defence springing from the general law and defined with none of the precision apparent in the legislation.

Despite the expansive constructions afforded to the statutory exceptions in recent case law, it is submitted that there remains an opportunity for a separate public interest defence to exist in specific circumstances where a fair dealing defence would not ordinarily be available. The public interest concerns which Parliament sought to address by the statutory exceptions are general ideals advocating unfettered public access to information and the free flow of ideas. A separate public interest defence would be narrower in scope, and address the enforceability of copyright in one of two circumstances - where the work is objectionable or immoral, or where the unauthorised publication serves a public good. The suggestion in several recent English cases of a public interest defence existing outside the statutory scheme ${ }^{13}$ is further evidence that the fair dealing exceptions fail to adequately address the public interest.

11 Pro Seiben Media AG v Carlton UK Television Ltd [1999] 1 WLR 605, 612 (CA) [Pro Seiben]. A similar expansive interpretation was provided by both the High Court and the Court of Appeal in Newspaper Licencing Agency v Marks and Spencer plc [1999] RPC 536 (HC) [Marks and Spencer].

12 Collier Constructions Pty Ltd v Foskett (1990) 19 IPR 44, 55 (HCA) per Gummow J [Collier Constructions].

13 See PRC Ltd v Dow Jones Telerate Ltd [1998] EMLR 407 [PCR]; Mars UK Ltd v Teknowledge Ltd [2000] FSR 138 [Mars]; Service Corpn International plc v Channel Four Television Corpn [1999] EMLR 83. 


\section{DEVELOPMENT OF THE PUBLIC INTEREST DEFENCE}

A The Public Interest - A "Robin Hood" Defence 14

The public interest defence has long been recognised in breach of confidence claims, and was originally limited to permitting the disclosure of iniquitous information. ${ }^{15}$ More recent cases have extended its scope to enable disclosure in breach of confidence where any "higher duty" for disclosure exists. ${ }^{16}$ The defendant need not prove any misconduct or iniquity on behalf of the plaintiff; even if the plaintiff acts lawfully and is innocent of any wrongdoing, the public interest can still override their rights because of the public interest served by the disclosure and publication of the relevant material.

What is in the "public interest" is to be ascertained by reference to policies and principles accepted by the community as a whole. ${ }^{17}$ As expected in a dynamic society, the concept of what constitutes the "public interest" changes over time, and this has been reflected in the case law that addresses the scope of the public interest defence.

\section{B The Public Interest Defence to Breach of Copyright}

The determination of copyright infringement involves a three-stage analysis. First, should copyright in the work be enforced? Secondly, are there any statutorily permitted uses of the work? Thirdly, if there are no permitted uses, what remedies should be available to the plaintiff to enforce his or her property rights in the work? Public interest considerations may be relevant at the first and last of these stages.

14 This description of the defence was used by Jeremy Phillips "The Berne Convention and the Public Interest" (1987) 9 EIPR 108, 114.

15 The earliest case, Gartside v Outram (1856) 26 LJ Ch 1131, held that there is "no confidence preventing the disclosure of iniquity". This was embraced by the courts in the late 1960s, in the cases of Initial Services Ltd v Putterill [1968] 1 QB 396 and Fraser v Evans [1969] 1 QB 349, where Lord Denning MR, in Fraser $v$ Evans, 405 stated that the defence extended to "any misconduct of such a nature that it ought in the public interest to be disclosed to others." In the case of Beloff $v$ Pressdam [1973] 2 QB 84 [Beloff], Justice Ungoed-Thomas articulated that the public interest extended to "matters carried out or contemplated, in breach of the country's security, or in breach of law, including statutory duty, fraud, or otherwise destructive of the country or its people."

16 Lion Laboratories Ltd v Evans [1985] QB 526 (CA) [Lion Laboratories].

17 G Dal Pont \& D Chalmers Equity and Trusts in New Zealand and Australia (Law Book Company, North Ryde, 1996) 104. 
A work may be so contrary to public policy and the public interest that the courts can, at the outset of the analysis, deny the author any protection afforded by copyright to the work. Otherwise, the public interest can be applied in the same way as it is to confidence, going to the issue of remedies (the third stage of the inquiry) and acting as a mitigating factor to the defendant's breach. When applied at either stage, the public interest may not be seen to be a 'defence' in the true sense of the word - a defence generally operates as a complete answer to an action for infringement. However, when the public interest acts to prevent the enforcement of copyright or restrict or deny the relief otherwise available, it can be seen as operating in a way analogous to a defence.

\section{Immoral works or those contrary to public policy}

In some early cases involving breach of copyright, the courts denied copyright protection to works that were of a grossly immoral tendency, ${ }^{18}$ were blasphemous ${ }^{19}$ or seditious in nature, ${ }^{20}$ or contained statements that were calculated to deceive the public. ${ }^{21}$ In such cases, while not denying copyright outright in such works, "[the] courts ... intervene[d] to prevent the author or copyright holder from enforcing or exercising those rights fully." 22

The other instance where the courts could refuse to enforce copyright is where the creator's actions so "reek of turpitude" 23 that it would be impossible for the State to uphold the copyright in the work. In the case of Attorney-General $v$ Guardian Newspapers (No 2), ${ }^{24}$ the

Stockdale v Onwhyn (1826) 5 B\&C 173; Baschet v London Illustrated Standard Co [1900] 1 Ch 73.

Lawrence $v$ Smith (1822) Jac 471; Murray v Benbow (1822) 1 Jac 474.

20 Hime v Dale (1804) 2 Camp 27n; Southey v Sherwood (1817) 2 Mer 435.

21 Slingsby v Bradford Patent Truck ETrolley Co [1906] WN 51; Hayward Bros v Lely E Co (1887) 56 LT 418.

22 Gerald Dworkin "Judicial Controls of Copyright on Public Policy Grounds" in Jan Kebel and Gerard Mom (eds) Intellectual Property and Information Law: Essays in Honour of Herman Cohen Jehoram (Kluwer Law International, The Hague, 1998) 141 ["Judicial Control"]. This approach reflects the rationale for copyright that property rights will be conferred on every creative work from the time of its creation. On a more practical level, if the work was devoid of copyright, the public interest would in fact be harmed rather than promoted, as the dissemination of the work could be undertaken without any threat of infringement and a second party could reproduce the work without restriction. This would defeat the reason why copyright was denied in the first place, namely to protect the public from these 'dangerous' works.

23 Attorney-General v Guardian Newspapers Ltd (No 2) [1990] AC 109 (HL) [Spycatcher].

24 Spycatcher, above $\mathrm{n} 24$. 
House of Lords recognised the courts' general equitable jurisdiction to decline to enforce copyright claims in cases where the work may be respectable but the author's actions had been tainted. On the basis that a creator should not be entitled to reap the benefits of his or her unlawful acts, the Law Lords declared it "inconceivable that a ... court would afford to [the author] or his publishers any protection in relation to any copyright which either of them may possess." 25

\section{Consideration of the public interest at the remedy stage}

In considering the public interest at the remedy stage of proceedings, the court can restrict the plaintiff's copyright by refusing relief on the grounds that, due to the particular circumstances of the case, the infringement is justified in the public interest. ${ }^{26}$ As Justice Jacob J observed in Hyde Park, "if equity prevents relief on the grounds of public interest, it in substance provides a complete defence to the entire claim." 27

Following the enactment of the CDPA and the inclusion of section 171(3), the savings provision for "any rule of law preventing or restricting the enforcement of copyright on the grounds of public interest or otherwise", there has been increased judicial discussion on the existence and status of the defence. However, the fact that some cases heard post-1988 have neglected to refer to section 171(3) suggests that the availability of the public interest defence is not dependent on its recognition in any statute. ${ }^{28}$

Not all jurisdictions support the existence of a separate common law public interest defence to breach of copyright. Judicial shadows have been cast upon the availability of the defence in

25 Spycatcher, above n 24, 293.

26 This application of the public interest defence dates back to the case of Lord and Lady Percival $v$ Phipps (1813) 2 V \& B 19; where injunctive relief in the publication of previously unpublished letters was withheld on the basis that the publication was in the public interest, effectively vindicating the infringement on the grounds of public interest.

27 Hyde Park (HC) above n 2, 670, see also Beloff, above n 16, 59

28 See Express Newspapers plc $v$ News (UK) Ltd [1990] 3 All ER 376, where the Court acknowledged the defence but refused to apply it on the facts; Beggars Banquet Records Ltd v Carlton Television Ltd [1993] EMLR 349. In these cases, the Judges recognised the relevance of public interest considerations in the sphere of copyright law, but did not refer to s 171(3). This was also the case in Hyde Park, where the defendants did not cite s 171(3) as the basis for their public interest defence. The most recent cases besides Hyde Park that have discussed the defence, namely ZYX Music Ltd v King [1995] 3 All ER 1, PCR above n 14, Mars above n 14, have all acknowledged the existence of the defence through s 171(3), but refused to apply it on the facts. 
Australia ${ }^{29}$ and Canada, ${ }^{30}$ but neither of these countries have a provision equivalent to section 171(3) in their respective copyright statutes. Similarly, the defence has been questioned in the United States, notwithstanding its doctrine of fair use, which being an equitable rule of reason is considerably wider than its Commonwealth fair dealing counterparts. ${ }^{31}$ New Zealand courts have yet to address the question, as no defendant has sought to invoke a common law public interest defence, nor the New Zealand equivalent to section 171(3) of the CDPA, section 225(3) of the Copyright Act 1994, in an action for breach of copyright. ${ }^{32}$

While English judges had seemed willing to recognise a defence outside the statute in exceptional circumstances, the Court of Appeal reversed this trend and placed doubt over the future of the public interest defence in its decision in Hyde Park.

\section{HYDE PARK RESIDENCES LTD V YELLAND - A U-TURN FOR THE PUBLIC INTEREST DEFENCE}

\section{A Background to the Case}

On 2 September 1998, the defendant, the Sun newspaper, published an article entitled "Video that Shames Fayed" accompanied by three video stills from a security camera owned by

29 Only the High Court of Australia decision in Commonwealth v John Fairfax \& Son Ltd (1980) 147 CLR 39 [John Fairfax] has recognised the defence. Subsequent judgments have rejected the defence. Collier Construction, above n 13; Smith Kline E French Laboratories (Australia) Ltd v Secretary, Department of Community Services and Health (1990) 17 IPR 545; Acohs Pty Ltd v RA Bashford Consulting Pty Ltd and Ors (1997) 37 IPR 542 In the latter case, Merkel J did not reject the relevance of the public interest altogether. Accepting that equitable discretion was available under the Copyright Act to refuse discretionary relief, the judge stated that "[t]he true underlying principle acted upon by the Courts for refusing relief on the grounds of public interest might lie in the discretion conferred as to the appropriate form of relief, rather than whether a defence disentitles a copyright owner to any relief."

30 Canadian courts have also rejected the defence, although its existence in England has been judicially acknowledged. See $R v$ Lorimer [1984] 1 FC 1065 per Mahoney J.

31 Whilst the court in Rosemount Enterprises Inc $v$ Random House Inc (1966) 366 F 2d 303 held that the public interest is an overriding consideration in the fair use analysis, the Supreme Court in Harper $\mathcal{E}$ Row Publishers Inc $v$ Nation Enterprises (1985) 105 S Ct 2218, 2230 held that the expansion of the fair use doctrine to allow a "public interest" exception would "threaten the very interests that the First Amendment and the Copyright Act were created to protect."

32 In Longman Group Ltd v Carrington Technical Institute Board of Governors [1991] 2 NZLR 574, 585 the defendants, citing Lion Laboratories, above n 17 as authority, submitted that a public interest defence outside the statute could be available, but acknowledged that in the particular circumstances of the case, it would not be. 
the plaintiff company, Hyde Park Residences Ltd. The pictures were misappropriated by an employee of the security firm, Mr Murrell, who sold them to the newspaper for a substantial sum of money.

The video stills showed Diana, Princess of Wales, and Dodi Al Fayed arriving at and departing from the Villa Windsor in Paris. The Sun alleged that it published the stills in order to discredit statements made by Mohamed Al Fayed concerning the time Princess Diana and Dodi Al Fayed spent at the property. According to the newspaper, Mohamed Al Fayed had made a series of statements, the most recent being just two days before the publication, about the circumstances surrounding the couple's subsequent deaths, including claims that the accident in which the couple died was in fact part of a conspiracy to prevent their imminent marriage. In support of his marriage postulation, Al Fayed had commented that the couple had spent two hours at the Villa with interior decorators and the like, suggesting they were planning to live there after their marriage.

In fact, the video stills showed that Princess Diana had only spent 28 minutes at the Villa. Although this information had been released into the public domain at an earlier time by $\mathrm{Al}$ Fayed's public relations spokesman, the newspaper published the stills to indicate the falsity of Al Fayed's statements.

Asserting copyright in the pictures, Hyde Park Residences Ltd brought summary judgment proceedings to determine the issue of infringement of copyright. ${ }^{33}$ The defendant newspaper raised the defences of fair dealing for the purposes of reporting current events under section 30(2) of the CDPA, and public interest. While not pleading the public interest defence under section 171(3) of the CDPA, the Court invariably discussed the defence in relation to that section.

\section{B High Court Decision}

Justice Jacob dismissed the summary judgment application, finding the defences of fair dealing and public interest had been made out. Following Lord Justice Walker's direction in Pro Seiben, Justice Jacob gave the phrase "reporting current events" a wide scope and found that the use of the video stills was "fair". ${ }^{34}$

33 The plaintiffs also alleged breach of confidence, breach of contract and inducement to breach contract.

34 Hyde Park (HC), above n 2, 662. 
Finding that fair dealing was made out, it was not necessary for the Judge to discuss the availability of a separate public interest defence. However, predicting that the case would be appealed, he felt an analysis of the public interest defence was desirable.

The plaintiffs argued that no separate public interest defence existed, maintaining that the statutory exception of fair dealing expressed the extent to which infringement could be justified. In the plaintiff's view, to allow the courts to enforce some undefined "public interest" limitation would amount to judicial legislating. ${ }^{35}$ In discussing the scope of section 171(3), plaintiff's counsel argued that it saved public interest considerations in relation to the question of relief only. They did not regard this as creating a specific public interest defence; rather the issue of the public interest was merely a factor in the analysis of whether to grant equitable or interlocutory remedies.

After examining the case law, including cases where copyright had been denied altogether and where it had been restricted by a public interest defence, Justice Jacob concluded that a "public interest defence" existed and was recognised - not merely "preserved" - by section 171(3). Considering the words in section 171(3), his Honour recognised the operation of the defence at two possible levels, first as a means of preventing the enforcement of copyright at the initial inquiry in respect of infringement, and second, at the remedial level, enabling the court to restrict the enforcement of copyright on public interest grounds. As to the scope of the defence, he suggested that it would succeed where "no right-thinking member of society would quarrel with the result."36 This would require a similar balancing exercise to that undertaken by the courts when reconciling the conflicting rights of freedom of expression and privacy under the law of confidence.

\section{Court of Appeal Decision}

In finding that there was no fair dealing, Lord Justice Aldous (Lord Justice Stuart-Smith concurring) concluded that the purpose of the newspaper's use was not reporting current events, and that, in any case, the dealing was not fair, giving particular weight to the fact that the work was unpublished and that the information could have (and had been) communicated without publishing the stills. He concluded that the raising of the defence "was an attempt to

35 Hyde Park (HC), above n 2, 661.

36 Hyde Park (HC) above n 2, 671. 
dress up the infringement of Hyde Park's copyright in the guise of reporting current events" and that to allow the defence would "give honour to dishonour."137

Furthermore, his Honour rejected the public interest defence, stating that section 171(3) in the CDPA "does not give the court a general power to enable an infringer to use another's property, namely his copyright, in the public interest." 38 His Honour reached this conclusion on the basis of three factors. First, copyright is a property right which is given by the 1988 Act and Chapter III of the Act provides for exceptions in the public interest; accordingly it would be wrong for a court, having rejected a fair dealing defence, to uphold a defence because publication was in the public interest. Secondly, "copyright is concerned with the protection of the form of the works in which copyright can subsist and not the protection of information." 39 Therefore, the weighing exercise undertaken in respect of disclosing confidential information need not apply to a copyright infringement claim, which would succeed regardless. Thirdly, "accepting a general defence of public interest would appear to be contrary to [England's] international obligations." 40

Thus deciding that there was no separate public interest defence to copyright infringement, Aldous LJ limited section 171(3) to a preservation of the courts' "inherent jurisdiction to refuse to enforce copyright...where the enforcement of copyright would offend against the policy of the law." 41 The exercise of this "inherent jurisdiction" would impliedly be in relation to refusing relief. His Honour stated that the circumstances where the court would be capable of exercising this jurisdiction were difficult to define, but could include situations where the copyright work alleged to be infringed was immoral, scandalous or contrary to family life, or was detrimental to public health and safety or the administration of justice.

Lord Justice Mance, giving an independent judgment, focused his reasons for denying the defence on the basis of the inherent differences between copyright, as a proprietary interest, and confidence, as a personal interest. The disparity between the nature of the rights meant that they could not be collaborated into one claim and defended with a common defence, namely that of public interest. Indeed, "the force of an owner's interest in the protection of his

37 Hyde Park (CA), above n 2, 617.
38 Hyde Park (CA), above n 2, 617.
39 Hyde Park (CA), above n 2, 621.
40 Hyde Park (CA), above n 2, 621.
41 Hyde Park (CA), above n 2, 619. 
copyright cannot be weighed in the same direct way against a public interest in knowing the truth." 42 Accordingly, he held that: ${ }^{43}$

there is an obvious need for caution about recognising any wider public interest in the same general area as discussed by section 30 , while the different considerations applicable to confidential information and copyright must on any view make the exercise of identifying an overriding public interest a different one.

Although doubting the validity of Lion Laboratories as an authority for a public interest defence to copyright, ${ }^{44}$ Lord Justice Mance seemed more inclined than his colleagues to recognise the scope for such a defence. ${ }^{45}$

\section{Effect of the Judgment}

When Justice Jacob's decision was released, it was hailed as a "welcome protection for media freedom." 46 The public interest defence, as recognised in section 171(3), could be used to refuse the enforcement of copyright in a repugnant work at the outset ("preventing the enforcement of copyright") or to refuse of a remedy in the particular circumstances of the case ("restricting the enforcement of copyright").

However, the Court of Appeal's decision had an equally radical effect - in the opposite direction. Not only did the appellate court impose a high threshold for the application of the fair dealing defences, but it also rejected outright the existence of a common law public interest defence to copyright infringement, instead limiting public interest considerations to the exercise of the court's "inherent jurisdiction." Free press advocates condemned the decision as

42 Hyde Park (CA), above n 2, 628.

43 Hyde Park (CA), above n 2, 628.

44 Mance LJ doubted the precedent value of Lion Laboratories for the public interest defence to copyright because the defendants did not raise a fair dealing defence. If a statutory defence had been raised, Mance LJ believed that the public interest defence would not have been accepted in relation to copyright.

45 Hyde Park (CA), above n 2, 630.

46 Jonathan Griffiths "Case Comment: Copyright: Whether Fair Dealing and In the Public Interest" (1999) 10 Ent LR 65, 65. 
an attempt by the courts to "curb the perceived 'excesses' of the press" and exercise tighter judicial control of the media. ${ }^{47}$

\section{$V$ CRITIQUE OF THE APPEAL COURT'S DECISION}

The Court of Appeal's limitation of the discretion exercisable to protect the public interest in relation to copyright actions under section 171(3) means that one can no longer refer to a public interest 'defence' at all. ${ }^{48}$ The decision was a complete reversal from the High Court's, which interpreted section $171(3)$ as creating a positive defence, capable of being invoked by a defendant in a copyright infringement action.

In rejecting the common law public interest defence in copyright, the Court of Appeal based its decision upon:

(1) the exhaustive nature of the statutory fair dealing exceptions;

(2) the perceived incompatibility of a separate public interest defence with the terms of international copyright conventions; and

(3) the discrepancies between the laws of confidence.

With all due respect, this reasoning is not irrefutable, and there are equally, if not more, convincing arguments in support of the recognition of a public interest defence in the sphere of copyright.

\section{A The Court of Appeal's Contradiction - a Codified 'Inherent Jurisdiction'}

The Court of Appeal's decision ultimately turned on its interpretation of section 171(3), which it regarded as merely recognising a court's inherent jurisdiction to refuse to allow its processes to be used in a way contrary to the policy of the law. With all due respect, such an interpretation is not only unjustified on the basis of precedent and policy in relation to copyright, but is also incorrect in relation to the court's powers. The whole purpose of the court's inherent jurisdiction is to allow flexibility in the application of the law. What the Court is suggesting is that section 171(3) codifies the jurisdiction. This unparalleled suggestion would have the effect of restricting the intrinsic flexibility of the jurisdiction, and undermine its 'inherent' nature, as it would subsist in the statutory regime.

47 Richard Browes "Case Comment - Copyright: Court of Appeal considers fair dealing defence and rejects common law defence of public interest" (2000) 22 EIPR 289, 292.

48 Robert Burrell, "Defending the Public Interest" (2000) 22 EIPR 394. 
The author submits that section 171(3) cannot be interpreted as the Court of Appeal suggests. First, it is both unprecedented and contradictory for the court to suggest that its inherent jurisdiction can be codified. There appears to be little reason in giving statutory recognition to something that exists as an inseparable component of the court's powers. Furthermore, codification distorts the very nature of the 'inherent' jurisdiction, and limits its application to those circumstances stipulated in the statute. Secondly, an investigation into the legislative history of the section indicates that Parliament intended the section to have a more purposeful scope than merely acknowledging the court's inherent powers in its analysis of remedies to copyright infringement.

\section{Legislative history of section 171(3)}

Prior to 1988, no copyright legislation in the United Kingdom had ever made express provision for other rules of law to operate to restrict or prevent the enforcement of copyright. ${ }^{49}$ However, as evidenced by the case law discussed earlier, this did not prevent the defence from being argued in copyright infringement claims in the place of, or in addition to, the statutory fair dealing exceptions. ${ }^{50}$

When the Whitford Committee was established to consider amendments to the 1956 Copyright Act, the newspaper publishing groups saw an opportunity to campaign for expanded permitted uses of copyright works. In addition to the suggestion from one group that publication of photographs be entitled to a fair dealing defence, ${ }^{51}$ the newspaper groups suggested that "publication 'in the public interest' should be admitted as a defence, subject possibly to some limit on the quantity or 'quality' of the material published." 52 During the readings of the Copyright, Designs and Patents Bill, several amendments were suggested that

49 The savings provision in the 1956 Act, s 46, only related to those areas where the Act did not apply and did not make express provision for the retention of rules of law preventing or restricting the enforcement of copyright

50 See Part III B above.

51 The group referred to an occasion where a photograph, published by one newspaper, became a matter of public interest, but because of the copyright was unable to published by other newspapers. The Committee's response to the suggestion to extend the fair dealing defence to photographs was unfavourable - it commented that such a concession would "reduce the economic interests of the owner of copyright in the photograph to a not inconsiderable extent." "Whitford Committee Report" above $\mathrm{n} 10,170$.

52 "Whitford Committee Report", above n 10, 170. 
attempted to introduce such a defence, but despite the advocacy by Lord Morton ${ }^{53}$ and Lord Lloyd, ${ }^{54}$ it never reached fruition. However, in what can only be seen as a conciliatory yet cautious move, the Government accepted, during the Third Reading of the Bill, the inclusion of section 171(3). The clause, then clause 161(3), invoked no discussion and was unanimously accepted by the House.

\section{Intended purpose of section 171(3)}

While some argue that "it would have been easy for the legislature... to [enact a public interest defence] expressly", 55 Parliament was concerned not to expressly undermine the fair dealing defences that covered the majority of foreseeable circumstances where copyright could justifiably be infringed. However, it recognised that the fair dealing defences may not be watertight, and thus retained, through section 171(3), the availability of the common law and equitable public interest defences to copyright infringement.

The enactment of section 171(3) has been criticised as a "rather hesitant" way of solving the issue of the status of the common law public defence to copyright. ${ }^{56}$ The section is particularly vague and fails to explicitly affirm the existence of the defence. However, it is obvious from the judicial environment at the time ${ }^{57}$ and the tenor of the House of Lords debates, that Parliament intended section 171(3) to have the effect of recognising a public interest defence to

53 Lord Morton advocated the acceptance of Amendment Nos, 124A and 78, which purported to add to clauses 29 and 31 respectively the rider that "Copyright is not infringed by anything done in the public interest." He supported his stance by reasoning that "the whole purpose of this clause is that the defences in copyright should be stated in the Bill rather than be left unknown, so that someone who is reading the Bill can see that there is a protection of public interest rather than having to know the common law of the land as well." (8 December 1987) 491 GBPD col 75.

54 Lord Lloyd moved Amendment No 20, which sought to add to $\mathrm{cl} 30$ the exception that "copyright is not infringed by anything done in the public interest to disclose a matter of grave public concern or the existence of a crime, fraud, abuse of authority or neglect in the performance of official duty or other misconduct." (28 March 1988) 495 GBPD, col 630. The addition of the circumstances when the public interest defence would arise sought to define the boundaries to the scope of the defence, and "elaborate what the term "public interest" means in the context of today." (28 March 1988) 495 GBPD, col 663. However, objectors argued that in so defining the public interest, the defence may become obsolete if the attitudes of society changed.

55 Dworkin, above n 22, 143.

56 Dworkin, above n 22, 143.

57 The CA's decision in Lion Laboratories, above n 17, and the Spycatcher, above n 24 was fresh in the minds of the Law Lords when the CDPA was being debated . 
copyright infringement. The section does more than merely 'hedge its bets' by preserving a public interest defence should it exist. ${ }^{58}$ It also goes further than recognising the court's powers to refuse equitable relief in the form of injunctions and damages should the facts so demand. In fact, the wording of section 171(3) indicates that it incorporates the two limbs of a public interest defence: ${ }^{59}$ (1) as a means of refusing a plaintiff to rely on his/her copyright to bring an action for infringement ("preventing enforcement"); and (2) by way of a defence in the particular circumstances of the case ("restricting enforcement").

In light of such an interpretation, the Court of Appeal's decision as to the purpose of section 171(3) can be seen, with due respect, as incorrect. In addition, the Court's rationale for rejecting the public interest defence in copyright is also questionable and requires critical analysis.

\section{B Other Reasoning Critiqued}

\section{Sufficiency of fair dealing defences}

While Lord Justice Aldous rightly recognised that the fair dealing defences serve to balance the competing interests in copyright, this is not of itself conclusive that the public interest considerations have been accommodated satisfactorily. In its analysis, the Court ignored the debate that ensued during the passage of the CDPA over the inclusion of a separate public interest defence in addition to the fair dealing exceptions. Although a concession was granted in terms of section 171(3), the extent and tenacity of the campaigning is indicative of the fact that some users of copyrighted material, most noticeably the newspaper publishers, regarded the fair dealing defences an inadequate. Furthermore, the Court ignored the fact that the fair dealing defence excludes photographs and unpublished works and is restricted to current events. ${ }^{60}$

In accepting the plaintiff's submission that the fair dealing defences "set out in detail the extent to which the public interest overrides copyright",61 the Court of Appeal failed to distinguish between the two notions of 'public interest' that may relevant in copyright. While general public interests - such as the public interest in the unfettered dissemination of works

58 Contrast Laddie, Prescott and Vitoria The Modern Law of Copyright and Designs (2 ed, Butterworths, London, 1995) 127.

59 See Part III B 1 and 2 above.

60 See Part VI A below.

61 Hyde Park (CA), above n 2, 617. 
and the free flow of information - are obviously accommodated in the statutory exceptions, the more specific public interest in censoring immoral works or in publishing works that serve to protect the public cannot be said to be the focus of the fair dealing defences. Universally conferred, copyright creates a formidable property right in a work that can be abused. It can be used to enable a creator to reap monetary rewards for an immoral or repugnant work, which is contrary to notions of morality and public interest, or employed as a weapon to prevent the revelation of material that is not itself protected subject matter. It is this notion of the 'public interest' - as a protector against the abuse of copyright - that is not accommodated by the fair dealing exceptions, and therefore justifies a separate defence.

\section{Inconsistency of public interest defence and international obligations}

Lord Justice Aldous noted that the Berne and Paris Conventions, in addition to certain European Directives, confer no mandate on individual countries to refuse to enforce copyright "if it is thought to be in the public interest of that State that it should not be enforced." 62 The only article referred to by the learned Judge was Article 10, which permits quotations from publicly available works. Clearly a public interest defence could not be justified under this Article. However, the Berne Convention also includes a general provision in Article 9(2) for member countries to: 63

permit reproduction of such works [that is, works protected under the Convention] in certain special cases, provided that such reproduction does not conflict with a normal exploitation of the work and does not unreasonably prejudice the legitimate interests of the author.

This being so, it is arguable that section 171(3) creates such a legislative exception for the otherwise unlawful reproduction of copyright works. As a public interest defence will only arise in exceptional circumstances where the harm to the public by non-publication would be greater than the harm to the author by infringement, it may constitute a "special case" under Article 9(2). Furthermore, it is unlikely that the publication of something in the public interest will conflict with the normal exploitation of the work, as in such cases, the author will not be seeking monetary recompense for his efforts. The work will most probably be confidential or at least deliberately unpublished in nature and, therefore, there will be no conflict with the creator's economic or other interests in the work. Indeed, it may only be the author's privacy

62 Hyde Park (CA), above n 2, 621.

63 The Berne Convention 1971 (Paris text), art 9(2). 
right that will be prejudiced. In such cases, if the public interest is sufficiently strong, an individual's right of privacy can be subordinated to the greater interests of the public.

\section{The clash between copyright and confidentiality}

Both Lord Justices Aldous and Mance intimated that the incompatibility between the law of confidence and copyright justified denying the extension of the public interest defence as it operates in confidence to the sphere of copyright. While there are significant differences between these two areas of law, most notably in their nature, ${ }^{64}$ origins, ${ }^{65}$ objectives $^{66}$ and the remedies available for their breach, ${ }^{67}$ these differences should not be the reason why a defence under one cannot be available under the other. The flexibility of case law and the ease with which it transplants legal doctrines from one body of law to another suggests that the extension of the defence from confidence to copyright is not as inconsistent as the Court suggests.

First, a breach of confidence will often involve infringement of copyright. ${ }^{68}$ Secondly, there will be circumstances where the idea and expression are so inextricably bound that the

64 The fundamental distinction often cited as the justification for treating the two areas of law differently is the nature of the interests at stake. The protection of confidences is a personal right whereas copyright is a proprietary interest. It is a principle of the law that property rights will not readily be overridden; personal rights are less stringently upheld.

65 Confidence is an equitable concept, whereas copyright is a purely statutory right. This was highlighted by Mason J in John Fairfax, above n 30, when he commented that the scope of the public interest defence to copyright was less extensive than that to a claim of breach of confidence, because the law of confidence has no statutory regime with stated exceptions, unlike copyright with its fair dealing exceptions.

66 Confidentiality, as a doctrine, is directed towards the preservation and privacy of information which is never intended to enter the public domain, whilst copyright aims to release works into the public sphere subject to restrictions on the use made of them.

67 The remedies available for each are different - a breach of confidence rarely results in the award of damages, and thus the plaintiff sees little pecuniary reward, whereas damages, including compensation or licence fees, are payable in the event of breach of copyright.

68 For example, if an employee of a company leaks a document to the press, he may well have taken a copy of the document and supplied that copy. In doing so, he has infringed the copyright subsisting in the work. Even if no copy is made and the original document is supplied to the press, who subsequently publish it, the newspaper will be guilty of infringement in issuing the copyright document to the public; David Lester \& Paul Mitchell Joyson-Hicks on UK Copyright Law (Sweet \& Maxwell, London, 1989) 204-5. 
idea/expression distinction cannot be made. ${ }^{69}$ This is most obvious in the case of visual images, such as photographs, where the work itself represents the leaked confidential information. In such a case, both the fair dealing exceptions and the idea/ expression dichotomy will be ineffectual in excusing the infringement, if the infringement is indeed justifiable. The only recourse for the defendant would be to rely on a defence that states that publication was justified in the public interest.

\section{Summary of the Critque}

With respect, the Court of Appeal's rationales for rejecting the public interest in Hyde Park are unsatisfactory and the judges take a particularly narrow view of the law that is neither based on precedent nor justified on policy grounds. The author believes that there is indeed scope for a common law public interest defence in the law of copyright.

\section{THE NEED FOR A PUBLIC INTEREST DEFENCE}

The debate over the need for a separate public interest defence is fairly well balanced. There are convincing arguments for both sides. However, as exemplified by the contrasting decisions in the two courts in Hyde Park. However, the limitations of the statutory fair dealing defences, the importance of freedom of expression, the extensive rights that copyright confers and the case law recognising the defence combine to provide a strong argument for the need for a separate public interest defence.

\section{A Inadequacy of the Statutory "Reporting Exception"}

The fair dealing exceptions in the CDPA justify the infringement of the plaintiff's copyright where the use made of a work is for the purposes of criticism, review, education or reporting current events. ${ }^{70}$ The "reporting exception" in sections 30(2) and (3) of the CDPA ${ }^{71}$ reflects the desire to preserve the freedom of the press to publish news reporting items without fear of infringing copyright. Indeed, the Court of Appeal in the recent case of Ashdown $v$ Telegraph Group Ltd ${ }^{72}$ held that the fair dealing defences would normally be sufficient for the court to reflect the public interest in the freedom of the press without separate consideration of the

\footnotetext{
69 Cary, above n 5, 171.

70 Sections 29-30 CDPA, ss 29-30 Copyright Act 1994, ss 42-43.

71 Copyright Act 1994, ss 42(2) and (3).

72 Ashdown v Telegraph Group Ltd [2001] EWCA Civ 1142 [Ashdown].
} 
availability of a section 171(3) defence. Furthermore, it reinforces the fundamental principle that there can be no copyright in facts, which ought to be in the public domain.

However, there are three significant omissions from the provision, namely photographs, non-current events and unpublished works. In the absence of an amendment to the fair dealing defence to accommodate these exclusions, a separate public interest defence is necessary.

\section{Exclusion of photographs}

The exclusion of photographs was a deliberate measure to protect the economic market in journalism photography and to preserve the intrinsic value contained in a visual image. It was believed that if a photograph of a newsworthy event could be used by a competitor without infringing copyright, there would be no incentive for photographers to catch current events on film. Accordingly, a proviso to the fair dealing defence in respect of photos was added to "place a premium upon a copyright photograph", ${ }^{73}$ and enable the owner of the copyright in a scoop photograph to refuse to permit reproduction of the image, or at least demand a substantial price for the use of it. ${ }^{74}$

Furthermore, as it is generally impossible to reproduce a photograph without copying the entirety of it, it was decided that the principles behind the fair dealing exception - most importantly its prohibition against the use of a work in its entirety - were not amenable to the reproduction of photographs. Somewhat inconsistently, however, the individual frames or stills from a video or film are covered by the fair dealing provisions. ${ }^{75}$

The inclusion of video stills, but exclusion of photographs, from the reporting exception creates anomalous decisions based purely on the mechanism used to create an image. The inconsistency is highlighted when applied to the facts in Hyde Park. The pictures at the centre

73 Susan Corbett "The Worth of a Picture: Photography, the Media and the Law of Copyright" (2000) 2 NZIPJ 201, 201.

74 Corbett, above n 75, 201.

75 The tenuous distinction between photographs and video stills was the result of the English Court of Appeal's decision in Spelling Goldberg Productions Inc v BPC Publishing Ltd [1981] RPC 283 (CA), where the Court held that a single frame, being part of a film, was not a photograph. Section 4(2) of the CDPA confirmed this distinction in the definition of photograph, which specifically distinguishes photographs from "part of a film." 
of the Hyde Park case were stills from a video, ${ }^{76}$ and thus the fair dealing was arguable. However, had they been photographs created by a camera, there would be no fair dealing defence and consequently the defendants would have no defence, unless a separate public interest defence existed.

Notwithstanding the particular value of some photographs, there appears to be no valid reason why the fair dealing defences should distinguish them and video stills, and apply the defence to one but not the other. Why should the defence legitimise the use when the image is, only by chance, derived from a video camera rather than a still camera? While a majority of video stills may be created without significant artistic input or will be derived from devices like stationary security cameras, photographs too can be created with very little skill or effort. In such cases, it is hard to rationalise the difference in the defences available to each.

While it is conceivable that the reporting exception could be reformed to allow photographs to be included, such an amendment is likely to completely extinguish the press photography industry. In many ways, the rationale behind the exclusion is justified and indeed desirable. However, there will be a lacuna in the defences available to infringers who use a photograph be it professional or amateur - if the idea represented in the image cannot be expressed in any other way. If the use of the photograph is deemed necessary for reporting an event of crucial public importance, a public interest defence should be available to justify the infringement of copyright. Such a defence is preferable to undermining the advantages gained by excluding photographs from the fair dealing defence.

\section{Restriction to current events}

Section 30(2) restricts the fair dealing reporting exception to events that are "current." To date, the courts have provided antithetical interpretations of this term and what is "current" appears to depend on judicial discretion. ${ }^{77}$

76 Jacob J in the High Court scrutinised the operation of the video camera that took the images of Princess Diana and Dodi Al Fayed and found that the images were 3 second moving images and thus distinguishable from 'photographs' (single time-delayed images).

77 Lord Justice Walker in Pro Seiben, above n 12 stated that a wide interpretation of the fair dealing exceptions was required, and this would presumably allow for a liberal definition of "current." However, the Court of Appeal in Marks and Spencer, above n 12 held that the mere fact that an article has appeared in the press is not of itself a "current event." 
While the terms "news reporting" and "non-current" seem incompatible, it is conceivable that copyright works containing confidential or historical material may at some stage be at the centre of a "current event". Although it is arguable that the impact of an unpermitted publication of confidential information could create a "current event" in itself, the narrow interpretation of "current events" presently favoured by the courts is likely to restrict this. Accordingly, in circumstances where old material is published, a defendant will most probably be restricted from seeking recourse to the reporting exception. ${ }^{78}$ In cases where the publication was necessary to protect the public, a public interest defence could come to the rescue.

\section{Inapplicability to unpublished works}

When assessing the applicability of the fair dealing exceptions, the most difficult determination is whether the use of the work was in fact "fair." What is fair will be a "matter of impression",79 although various factors have been held to influence this decision. One such factor is the unpublished nature of the work. The courts have been extremely reluctant to find that publication of a previously unpublished work will constitute fair dealing. ${ }^{80}$ Therefore, if an unpublished document, such as a confidential government paper, has never been circulated in the public domain, ${ }^{81}$ it is unlikely that the court will find the use to be fair dealing,

78 There is a clear line of authority that the fair dealing exception can only apply to publication of current documents that relate to current events. For example, Distillers Co. Biochemicals Ltd $v$ The Times Newspapers Ltd [1975] QB 613 [Distillers], where the Court held that that the publication of twelve-year old documents relating to the thalidomide tragedy, which was of current interest, did not fall under the fair dealing exception for reporting "current events" as the copyright material was not itself current. Also see decision in Associated Newspaper Group Plc v Newsgroup Newspapers Ltd [1986] RPC 515, where the death of the Duchess of Windsor was the "current event" and historical love letters could not be justifiably published on the basis that they constituted a "current event" as they were merely related to the event in the news. However, in that case, Walton J did not exclude all non-current material from the defence.

79 Hubbard v Vosper [1972] 2 QB 84, 94.

80 For example, British Oxygen Company Ltd v Liquid Air Ltd [1925] 1 Ch 383; Distillers, above $\mathrm{n}$ 80; but also see Fraser $v$ Evams, above $\mathrm{n} 16$ and Hubbard, above n 81, where the publication of unpublished works was still held to be fair dealing, due to the serious danger the works posed to public and national safety.

81 If the work has been circulated amongst a few members of the government, this will not amount to a release into the public domain. The 'unpublished' status of the work would be likely to remain, as 'publication' may not occur when a work is distributed to a select few on a confidential basis. 
notwithstanding the relevance of the work to the public interest. A separate public interest defence would permit unpublished works attaining the high threshold of public interest to be published.

\section{B Importance of Freedom of Expression}

The need for a public interest defence is often premised on the right to freedom of expression. One of the key objections often raised to enforcement of copyright is that it enables private property rights to trump this fundamental human right.

Freedom of expression should not been seen as completely irreconcilable with copyright. While freedom of expression is an important consideration in relation to copyright, it must be remembered that copyright is not generally used to prevent speech altogether, which is the most common situation when free speech arguments arise. Rather, the purpose of copyright is to protect the commercial interests of the original speaker. ${ }^{82}$ However, there will be circumstances where copyright protection will not only restrict the dissemination of the expression, but also have the effect of suppressing the information it contains. Such circumstances will be those where the idea/expression dichotomy is inseparable. In such cases, copyright in the expression will effectively confer copyright in the ideas, and therefore, freedom of expression will be denied. In such cases, a public interest defence may be justified to ensure freedom of expression.

\section{Impact of the European Convention on Human Rights}

The impact of the Human Rights Act 1998 on copyright law was recently addressed in the English Court of Appeal decision in Ashdown v Telegraph Group Ltd. ${ }^{83}$ The case concerned the publication of an unpublished minute of a meeting between the plaintiff, a Member of Parliament, and the British Prime Minister. The newspaper tried to argue, in addition to the statutory fair dealing defence and public interest defence in section 171(3), a defence of freedom of expression contained in Article 10 of the European Convention on Human Rights and Fundamental Freedoms 1950 (ECHR), enshrined in English law in section 12(4) of the Human Rights Act 1988 (HRA). The Court of Appeal upheld the decision of Vice-Chancellor Morritt at first instance, where the learned judge held that Article 10 of the ECHR could not influence the interpretation of the CDPA. The newspaper had attempted to argue that in

82 Richard Stone "Review of Yearbook of Media and Entertainment Law, Vol II, 1996" <http://elj.warwick.ac.uk/jilt/BookRev/97_ston/stone.htm> (last accessed 21 September 2000).

83 Ashdown, above $\mathrm{n} 73$. 
circumstances where statutory defences were not available, the court should nevertheless consider whether, in the circumstances of the case, the restriction on the right to freedom of expression imposed by the CDPA was necessary in a democratic society (under Article 10(2)(iii)). Both Courts rejected this argument, but conceded that in circumstances where the right of freedom of expression conflicted with copyright protection, the court was bound to apply the CDPA in a manner that accommodated the right of freedom of expression enshrined by the HRA. ${ }^{84}$

It must be noted that Article 10 does not require absolute protection for freedom of expression. Interferences with the right will be permitted, but must be both necessary to meet a "pressing social need" and strictly proportionate to their purpose. ${ }^{85}$

Notwithstanding the decision in Ashdown, the enactment of the HRA may, in certain circumstances, provide a justification for recognising a public interest defence. Although the fair dealing defences will generally satisfy the requirements in section 12(4), in certain circumstances "the application of copyright law may represent a disproportionate interference with the public interest in 'receiving and imparting information and ideas' and the HRA may have an impact ... provid[ing] a means by which ... the judiciary can shape copyright law more closely to the public interest." 86

In the New Zealand context, section 14 of the Bill of Rights Act 1990 guarantees that:

[e]veryone has the right to freedom of expression, including the right to seek, receive and impart information and opinions of any kind in any form.

The Bill of Rights Act requires that statutes, such as the Copyright Act, be interpreted as consistently as possible with the rights contained in the Act. In the event of inconsistency, the statute, not the Bill of Rights, prevails. ${ }^{87}$ However, there is no provision in the Bill of Rights Act in respect of inconsistent common law rules, and thus the conclusion can be drawn that

84 HRA 1998, s 3.

85 Jonathan Griffiths "Copyright in English Literature: Denying the Public Domain" (2000) 22 EIPR 150.

86 Griffiths, above n 77, 153.

87 Bill of Rights Act 1990, ss 6 and 4. Compare to the superiority afforded to the First Amendment in the United States, which guarantees freedom of expression. 
"judges are free to use the Bill of Rights to develop principles of law [such as a common law public interest defence to copyright infringement] in this area." 88

\section{Relevance of Case Law and Section 171(3) CDPA}

Over the last 30 years, many judges have recognised the existence of a separate public interest defence to actions of breach of copyright. ${ }^{89}$ However, complete conferral is far away, and the defence has its fair share of dissidents. One criticism of the defence is that it cannot stand up on its own, and only succeeds where there is a concurrent claim of breach of confidence. ${ }^{90}$ The author submits this is not a valid reason to dismiss the defence. The situations when copyright is infringed on the basis that 'the public ought to know' will most likely be those where the information contained in the copyrighted work is confidential in nature. ${ }^{91}$ Indeed, as Dworkin and Taylor observed, "[n]ot to allow public interest as a defence to infringement of copyright would seriously undermine its utility as a defence to breach of confidence." ${ }^{12}$

A further criticism is that the cases in which the defence has been upheld have been interlocutory hearings sought as a matter of urgency, ${ }^{93}$ thus depreciating their precedent value. However, this is unjustified as the very nature of copyright and the remedies available for infringement - the most common being injunctions - means that most cases only proceed as far as the interlocutory level.

88 Joanne Oliver Copyright and Freedom of Expression (LLM Research Paper, Victoria University of Wellington, 1997) 43.

89 See Part III B above.

90 This criticism is fuelled by Laddie and others, above $n$ 60, 127 who state that in the only cases where the defence has been recognised, "the real or principal claim has been one for misuse of confidential information and a copyright infringement claim has been tacked on almost as an afterthought."

91 "Often someone seeking an injunction to restrain breach of confidence will also have a right to an action in copyright": Gerald Dworkin and Richard Taylor Blackstone's Guide to the Copyright, Designs and Patents Act 1988 (Blackstone Press, London, 1990) 81.

92 Dworkin and Taylor, above $\mathrm{n} 93,82$.

93 Laddie and others, above n 60, 127. 
Finally, section 171(3) in the CDPA cannot be ignored - its inclusion in the statute can only be seen to "re-crystallise" 94 the existence of the defence in relation to copyright that was recognised in the case law in the 1970s and 1980s. It is a fundamental tenet of the rule of law that Parliament will never enact a statutory provision without good cause. The author submits that the intention behind section 171(3) was to recognise the public interest defence to copyright infringement, either to justify copyright infringement where a work is so immoral or repugnant that copyright cannot subsist in it, or where the publication will serve to reveal wrongdoings, assist in the administration of justice or disclose threats to the public health or safety. The defence is a positive one, capable of being raised by the defendant in the event that the fair dealing defences are not available to him or her. It is not exercisable merely in the court's inherent jurisdiction, as the Court of Appeal suggested. Had this been Parliament's intention, there would be no reason to enact the section at all. Indeed, legislating an "inherent jurisdiction" is nonsensical and contrary to the very nature of the court's power. Section 171(3) was intended to have a more meaningful existence - that of recognising the availability of a public interest defence in copyright law.

\section{THE SCOPE OF THE PUBLIC INTEREST DEFENCE IN COPYRIGHT}

Having provided legal and policy justifications for the recognition of a separate public interest defence to copyright infringement, it now remains to delineate the scope of the defence.

\section{A The Two Uses of the Defence}

The author suggests that the wording of section 171(3) allows a public interest defence to operate at the initial and remedial stages of the analysis of copyright infringement. The Court can prevent the enforcement of copyright at the first stage of the analysis by disallowing a copyright holder to bring an action where his or her work is considered immoral and/or reprehensible, or can restrict relief in the last stage of the analysis, once copyright has been established.

It is submitted that the defence will arise more in the latter stage to restrict the granting of relief for infringement of copyright. Although public policy and the public interest may prevent the plaintiff who has produced an immoral work actually making out a cause of action, the analysis of this by the courts is notoriously difficult and will change over time and

94 Geoff McLay "Being fair to users: the welcome arrival of a new, more liberal approach to fair dealing" (1999) 2 NZIPJ 135, 136. 
between judges. Indeed, "while the courts will still refuse their assistance to material which has a grossly immoral tendency, there is no common view as to what kind of ... conduct is grossly immoral." 95 Judges nowadays are significantly more tolerant of what may have been regarded in the past as 'immoral' works, ${ }^{96}$ and are reticent to make morally-influenced decisions. Furthermore, "there can be an element of hypocrisy in raising a 'gross immorality' defence to excuse a publication", ${ }^{97}$ as it would enable the objectionable work to be disseminated more freely as it can be copied at will without the infringer fearing any enforcement action.

\section{B Determining the 'Public Interest' Threshold}

The circumstances in which the public interest defence should operate are difficult to prescribe. The defence has been described as one as to which there are "many opinions but few guidelines." 98

\section{Circumstances when the defence will arise}

Ultimately, the availability of a public interest defence will depend entirely on the particular facts. While the potential scope of the defence to copyright may be impossible to define, guidance can be gleaned from the application of the defence to breach of confidence. Indeed, it has been suggested that "the concept of a defence of 'public interest' in publication appears to be the same for both." 99 However, factors such as the status of the plaintiff, the prior publication of the work or the defendant's conduct in obtaining the copyright material may also influence the ultimate success of the defence.

It is submitted that the public interest defence will be available in copyright cases when:

95 Geoffrey Robertson and Andrew Nichol Media Law: The Rights of Journalists and Broadcasters (2 ed, Longman, London, 1990) 184.

96 In Stephens v Avery [1988] 2 All ER 477, 480 Browne-Wilkinson VC commented, that "the works of Elinor Glyn, if published today would widely be regarded as, at the very highest, very soft pornography."

97 Robertson and Nichols, above n 97, 185.

98 J F Burrows "Developments in Media Law" (Legal Research Foundation Seminar, 25 February 1988) 17, 42.

99 JP Skone James and others Copinger and Skone James on Copyright (14 ed, Sweet \& Maxwell, London, 1999) 
(1) a work is, from an objective perspective, immoral or repugnant to the integrity of society; 100 or

(2) the creator's conduct has been so disgraceful that the courts will not enforce his or her copyright; ${ }^{101}$ or

(3) there is a disclosure of a wrongdoing and the administration of justice is best facilitated by publication of a copyright work; or

(4) the disclosure by means of publication will prevent the public from being misled and in doing so protect their health and safety; ${ }^{102}$ or

(5) information deliberately being kept secret by the government is published in its original form.

The real difficulty is in determining exactly when the public interest requiring publication outweighs the proprietary interest in copyright. ${ }^{103}$ The application of the defence to copyright should be governed by general principles of law, but should also involve a consideration of the four particular principles enunciated by Lord Stephenson in Lion Laboratories, namely that: ${ }^{104}$

(1) there is a difference between what is interesting to the public and what is in the public interest; 105

(2) it is a fact that the media, for example newspaper proprietors, have a private interest to increase circulation by publishing what appeals to the public; ${ }^{106}$

100 See Part III C 1 above.

101 Such as in Spycatcher, above $\mathrm{n} 24$.

102 In Lion Laboratories, above $\mathrm{n}$ 17, the publication of the memorandum served to prevent the public being misled as to the effectiveness of the breath-testing devices Mason J in John Fairfax, above n 30, described the application of the defence to protect the public from "damage, destruction or harm."

103 A Brown and A Grant Law of Intellectual Property in New Zealand (Butterworths, Wellington, 1989) 419.

104 Lion Laboratories, above n 17, 536.

105 This point was articulated by Megarry VC in British Steel Corporation v Granada Television Ltd [1981] AC 1096, 1113, that judges do not use the term 'public interest' "in the sense of something which catches the interest of the public out of curiosity or amusement, but in the sense of something which is of serious concern and benefit to the public."

106 This point was highlighted in Sir John Donaldson MR's judgment in Francome v Mirror Group Newspapers Limited [1984] 1 WLR 892, 898B. 
(3) the public interest might be best served by giving the information to the police or some other responsible body rather than the press; ${ }^{107}$ and

(4) the public interest did not only arise when there was an iniquity to be disclosed and the defendant ought not to be restrained solely because what he wants to publish did not show misconduct on the part of the plaintiff. ${ }^{108}$

Once these factors have been considered, the court will be in a better position to determine whether there is a legitimate 'public interest' that will be served by publishing the work in breach of copyright.

\section{The status of the plaintiff}

Any application of the public interest defence should take into account the private or public status of the plaintiff. The defence should not be used as a justification to unconditionally invade people's personal lives. Rarely will the publication of material relating to an individual's private life actually be in the public interest. ${ }^{109}$ The exceptions to this may be the Royal Family and certain persons who have placed their lives under public scrutiny. Although not serving the traditional protective "public interest" function, publication of material relating to these individuals may in fact be in the public interest. ${ }^{110}$ However, in such cases, the line between what is in the public interest and what is of interest to the public will be very hard to distinguish. ${ }^{111}$ The general standard for the application of the public interest defence in cases concerning private plaintiffs should be when the plaintiff's only interest in preventing

107 This was suggested by Lord Denning MR in Initial Services, above n 16, 405-6.

108 See scope of defence as discussed in Part III B above.

109 Compare Graeme Johnston, "Copyright and Freedom of the Media: A Modest Proposal" (1996) 18 EIPR 6,13 where the author states that the private plaintiff should only win in the most clear cases. This gives a particularly expansive (and unjustified) scope to the defence in relation to an individual's property.

110 In Woodward $v$ Hutchins [1977] 1 WLR 760 which concerned disclosures about the sordid antics of member of a pop group, Lord Denning stated, at 763, that "if a group ...seek[s] publicity which is to their advantage ... they cannot complain if a servant or employee of theirs afterwards discloses the truth about them. If the image that they fostered is not a true image, it is in the public interest that it should be corrected."

111 See Express Newspapers, above n 29, where Browne-Wilkinson held that publication of comments by a distant member of the Royal Family about childbirth out of wedlock was not amenable to the public interest defence as it fell on the 'of interest to the public' side of the threshold. 
publication is due to embarrassment, disagreement or outrage, as "such interests are not the kind of thing which copyright is intended to protect." 112

In contrast, public plaintiffs, such as governments, must show good reasons for refusing to publish material

\section{The effect of prior publication}

Copyright protection arises upon the creation of the work, and the fact that a work remains unpublished will not derogate from the enforceable property rights that are afforded to it. The unpublished nature of a work is a factor that often countervails against a finding of 'fair dealing.' This is because the courts regard the proprietor's right of exploitation of the work as the most valuable feature of copyright protection. If an unpublished work is released into the public domain by an infringer, the courts will be very reluctant to uphold a defence fair dealing.

In the case of works that are published in furtherance of the public interest, the published or unpublished status of the work will modify the rationale for the defence. "The basis of the defence, being that the public needs to know ... goes once such information has been disclosed to all."113 According it is difficult to see how the defence can be applied to published works. It would only be feasible if the publication serves to disseminate the information to a wider group of the public. An example of this would be a government document containing sensitive information of relevance to the country's well being, which has been published and distributed amongst a group of politicians, but later finds its way into the hand of a newspaper publisher. If the information contained in the document satisfied the 'public interest' threshold for publication, the further dissemination of the work in the public domain would be justified on grounds of public interest.

However, when a private and unpublished document that would otherwise be protected by copyright is published and exposes something the public ought to know, the rationale for the existence of the defence is satisfied. It is submitted that the defence should be applied in circumstances where the material is unpublished and the owner wishes to keep it that way, or where delays in publication arise because of disputes as to the ownership of copyright. ${ }^{114}$

112 Johnston, above n 111, 14.

113 Express Newspapers, above n 29, 382.

114 Meena Sayal "Copyright and the Freedom of the Media: A Balancing Exercise" (1995) 6 EIPR $263,273$. 
At first blush, the restriction of the defence to unpublished works appears to brazenly violate the privacy rights of the creator and also his or her right of first publication. However, if the unpublished material is crucial to the public's well-being, the effective administration of justice or the protection of national safety, the individual's private rights may be legitimately subordinated in favour of the public benefit gained by infringing copyright.

\section{The defendant's misconduct in obtaining the work}

Similar to other discretionary concepts, it seems that the public interest defence would require defendants to come to the court with 'clean hands.' In other words, the party seeking to rely on the court's equitable power with regard to relief must themselves have acted lawfully and fairly. On a strict application of the equitable maxim, a defendant who has obtained the copyright work through criminal or immoral means cannot demand the protection of equity.

However, the public interest in the publication of the work may mitigate the defendant's wrongdoing. It is often the case that obtaining information that is in the public interest and is intended to be kept away from the public involves some degree of underhand activity. ${ }^{115}$ If the publication is in fact found to legitimately serve the public interest, the defendant's misconduct in obtaining the work should be disregarded. Similarly, the fact that the defendant makes a profit from the publication may also have little impact on the availability of the defence. It is submitted that in such cases the harm or danger averted by the publication is more important than the arguably unethical receipt of money for the work.

\section{Availability of the Defence}

Section 171(2) of the CDPA (and section 225(2) of New Zealand's Copyright Act 1994) states that, subject to section 171(1), 116 "no copyright or other right in the nature of copyright shall exist otherwise than under this Act." Interestingly, that declaration of exclusivity is not subject to section $171(3)$.

Prior to the enactment of section 171(3), one commentator declared that "it would require some boldness to add a common law defence to the statutory ones." 117 The inclusion of section

115 Johnston, above n 111, 16.

116 Section 171(1) recognises and retains, among other things, rights arising under other statutes, prerogative rights of the Crown, and any rules of equity relating to breaches of trust or confidence.

117 J F Burrows News Media Law in New Zealand (3 ed, Oxford University Press, Auckland, 1990), 122, speaking in relation to New Zealand's Copyright Act 1962, which like its English counterpart at the time, the Copyright Act 1952, had no equivalent to s 171(3). 
171(3) into the CDPA can only be seen as Parliamentary acceptance of the existence of a common law public interest defence in the realm of copyright. To give the section any other interpretation results in an injustice to the wording of that section and the policy behind it.

However, the scope of this separate defence should be limited so it does not operate as a "last refuge of the copyright scoundrel". ${ }^{118}$ As Lloyd J cautioned in PRC Limited $v$ Dow Jones Telerate $L t d,{ }^{119}$ the extra-statutory public interest defence should not be applied in ways that are inconsistent with or undermine the specific statutory fair dealing defences. Indeed, it should only be accepted by the court when the defendant's legitimate free expression might otherwise be curtailed by a failure to fall within the defined fair dealing exceptions in the copyright legislation. In keeping with Parliament's intentions, as expressed through section 171(2), any common law defence should complement the statute rather than override it.

\section{CONCLUSION}

The existence - or not - of a separate public interest defence in copyright law has been the subject of much judicial speculation over the years. In the author's view, the decision in Court of Appeal in Hyde Park, rejecting the defence and limiting public interest considerations to the exercise of the courts' inherent jurisdiction, not only involves an unjustifiably narrow reading of section 171(3) in England's copyright statute, but also ignores the convincing policy reasons supporting the need for the defence in copyright.

The author submits that the public interest defence is a necessary part of copyright law. It fills a lacuna in the defences available to parties who infringe copyright with the good motives of trying to protect the public, yet to whom, for various reasons, the statutory exceptions to infringement do not apply. The defence should be available to prevent the enforcement of copyright in objectionable works, or to restrict copyright enforcement via the refusal of remedies to the plaintiff. The latter use of the defence will operate in circumstances where the publication of the copyright material serves the public interest in disclosing wrongdoings, preventing the public from harm, or enhancing national safety. The four principles enunciated in Lion Laboratories, in addition to considerations of the nature of the work and the status of the plaintiff, should guide the application of the defence.

118 McLay, above n 95, 137

119 PRC, above $\mathrm{n} 14$. 
Caution must be exercised to ensure the scope of the defence does not override the statutory fair dealing exceptions, which were enacted for the very purpose of balancing the rights of copyright owners with the needs of the public. The balance is a fine one. The defence should never become tantamount to a "thieves' charter."120

An analysis of the history of the public interest defence in copyright law shows that it has had a rather controversial and contentious existence. It remains to be seen whether the decision in Hyde Park has in fact spelt the demise of the defence, or whether, as in the past, the defence will recover from this setback and emerge as an even more formidable weapon in the defendant's arsenal against claims of infringement. However, until the unique set of facts that warrants the application of the defence arises again, we can only contemplate what future the public interest defence has in the law of copyright.

120 This turn of phrase was used by David Bradshaw in his article "Fair Dealing and the Clockwork Orange Case: A Thieves' Charter" (1994) 5 Ent LR 6. 
